Int. J. Morphol.,

28(3):829-834, 2010

\title{
Expression of Death Cellular Receptors FAS/CD95 and DR4 During Porcine Placentation
}

\author{
Expresión de los Receptores de Muerte Celular FAS/CD95 y DR4 Durante la Placentación Porcina
}

\author{
${ }^{*}$ C. Merkis; ${ }^{* *}$ A. Cristofolini; **E. Sanchis \& *M. Koncurat
}

MERKIS, C.; CRISTOFOLINI, A.; SANCHIS, E. \& KONCURAT, M. Expression of death cellular receptors FAS/CD95 and DR4 during porcine placentation. Int. J. Morphol., 28(3):829-834, 2010.

SUMMARY: Apoptosis is a permanent and dynamic physiological process by which an organism eliminates the undesirable cells without causing an inflammatory response. The objective of this work was to study the expression of FAS, DR4 and other members of the TNF-R1 superfamily extrinsic route apoptotic receptors the DNA fragmentation and the cellular apoptosis in placental samples at the early, mid and late pregnancy on $\pm 30, \pm 55$ and \pm 114 gestational days, respectively. We used placental histological sections of samples fixed in buffered saline formaldehyde. Immunohistochemical techniques were performed to detect the apoptotic receptors, whereas the DNA fragmentation was detected by TUNEL reaction and apoptotic cellular ultrastructure was detected by TEM conventional techniques. Apoptosis related receptors were immunolocalized in the early pig gestation and correlated with apoptosis, suggesting a role in the cellular remodelling of the placenta. At gestation day 55, apoptosis might be correlated to FAS route, but not by DR4-mediating pathway. At the end of gestation, increased apoptosis and both receptors markers were detected showing cellular death due to the extrinsic route through FAS and DR4 receptors. In conclusion, the immunolocalization of FAS and TNF R-1 receptors along the pig placental development correlates with TUNEL reaction and with apoptotic ultrastructure observed by TEM and seems to occur through different pathways along gestation.

KEY WORDS: FAS/CD95; DR4 and TNF-R1 family; Apoptosis receptors; Pig placenta.

\section{INTRODUCTION}

The apoptosis or programmed cellular death is an essential, permanent, dynamic and interactive biological process by which an organism eliminates the undesirable cells without causing an inflammatory response. The sequence of characteristic apoptotic processes is regulated by the interrelation of pro and anti apoptotic mechanisms, so the cellular death can be inhibited, balanced or stimulated (King \& Cidlowski, 1998; Ameisne, 2002; Jersak \& Bischof, 2002; Adams, 2003; Van Gurp et al., 2003; Fink \& Cookson, 2005).

The programmed cellular death constitutes a key factor in the development of different physiological processes such as the placentation, an essential reproductive phenomenon in most mammals. It can be induced through intrinsic or mitocondrial route or by extrinsic route that begins by binding of ligands to membrane receptors. The best characterized cellular death receptors are FAS/CD95,
DR4 and TNF-R1 (Yang \& Korsmeryer, 1996; Barnhart et al., 2003; Inoue et al., 2003; Lavrik et al., 2005).

Early gestation in pigs, is characterized by rapid development and growth of the uterus and the embryos, resulting in the formation of an epitheliochorial, diffuse, noninvasive, folded and adeciduate placenta. The placenta plays a fundamental role during the gestation, allowing the implantation and maintenance of the pregnancy, and also determining the survival of the piglets (Amoroso, 1952; Dantzer, 1985; Dantzer \& Leiser, 1993; Leiser \& Kaufmann, 1994; Van der Lende \& Van Rens, 2003).

One of the mechanisms of tissues remodelling regulation in both humans and animals is apoptosis (Hardy et al., 2001). Preliminary reports on remodelling of porcine placental cells have been done in our laboratory through morphologic and immunohistochemical detection of

\footnotetext{
* Electronic Microscopy Area. Faculty of Agronomy and Veterinary. National University of Río Cuarto, Argentina.

* Consejo Nacional de Investigaciones Científicas y Técnicas, CONICET. Río Cuarto. Córdoba, Argentina.
} 
apoptosis, in an attempt to characterize this process during porcine placentation (Merkis et al., 2007; Cristofolini et al., 2007).

In pigs, early embryonic mortality without specificinfectious or toxic cause ranges between 30 to $40 \%$, most of them occurring before Day 30 of gestation (Lawrence, 1993; Pope, 1994). However, in our geographical area, Río Cuarto (Argentina), this percentage can reach values up to 50$52 \%$ (Bosch et al., 2001). Therefore, determination of the basic mechanisms that trigger cell placental death or survival through key molecules identification during porcine gestation, will allow deepening the knowledge on physiological mechanisms that contributes for a successful pregnancy. This knowledge might be used to increase the survival of the embryos/fetus and to improve the pig reproductive health, collaborating with the high productive and valuable pig industry of our region.

The aim of this work was to study the expression of FAS, DR4 and other members of the TNF-R1 superfamily extrinsic route apoptotic receptors by immunohistochemistry, DNA fragmentation by TUNEL and the apoptotic cellular ultrastructure by TEM in placental samples from early $( \pm$ 30 days), mid ( \pm 55 days) and late gestation ( \pm 114 days), in order to analyze the apoptotic process associated with porcine placentation.

\section{MATERIAL AND METHOD}

Mixed breed swines from a pig breeding establishment of Río Cuarto city, Córdoba, Argentina (33.11 ${ }^{\circ} \mathrm{S} ; 64.3^{\circ}$ O) were used. According to the antemortem and postmortem examinations they were considered free of disease. Of these bristles, a total of 15 placentas were processed: \pm 30 days of gestation $(n=5), \pm 55$ days $(n=5)$ and upon maturity (approximately 114 days of pregnancy) $(n=5)$. In all cases the reproductive tract was removed immediately after slaughter, washed with saline solution of Hank's (SSH) containing sodic penicillin G, streptomycine sulphate and fungizone (Gibco, Grand Island, NY USA) and was maintained at $4^{\circ} \mathrm{C}$ until processing in the laboratory. Palpation was made to detect the location of the embryos or fetuses. The uterine horns were opened carefully and longitudinally with an incision on the anti-mesometrial edge to observe the implantation site and to gather samples of mesometrial endometrial and fetal placental tissues. Portions of approximately $6 \mathrm{~mm}$ each were taken from 5 placentas of every gestational period, fixed in 4 per cent $(\mathrm{v} / \mathrm{v})$ bufferedsaline formaldehyde, $\mathrm{pH} 7.2-7.4$ at $4^{\circ} \mathrm{C}$ and embedded in paraffin. From these paraffin-embedded tissues, histological sections of $\pm 4 \mu \mathrm{m}$ were obtained. The gestational age of the placentas was determined according to the crown-rump length of the embryos and/or fetuses obtained of each gestating bristle (Marrable, 1971).

Immunohistochemical techniques were performed using Santa Cruz, Inc. commercial antibodies: FAS (B-10), that recognizes FAS receptor and other members of the TNF R-1 superfamily, FAS (C-20), that recognizes only FAS receptor and DR4 that binds DR4 receptors, biotinylated secundary antibodies pool, streptavidin conjugated to horseradish peroxidase $\left(\mathrm{LSAB}{ }^{\circledR}+\right.$ Systems HRP, Dako Cytomation) and 3,3'-diaminobenzidine chromogen solution (Liquid DAB +Substrate Chromogen System, Dako Cytomation). The sections were counterstained with Mayer's haematoxylin. The results were expressed as semiquantitative values, determining: $(-)$ : negative, $(+)$ : weak, $(++)$ : moderate and $(+++)$ : strong immunostaining. For every gestational period the distribution of the immunolabelling intensity was determined by means of the High Score value (Selam et al., 2001). Simultaneously, immunohistochemical negative controls were carried out.

The detection of the DNA fragmentation was made by means of TUNEL technique (TdT-mediated-dUtp Nick End Labeling) using commercial equipment ApopTag ${ }^{\circledR}$ (Chemicon International). The samples were observed in a light microscope Axiophot (Carl Zeiss) and the images acquired realized with a digital camera Powershot G6, 7.1 megapixels (Canon INC, Japan). The results were expressed as cualitative.

For electron microscopy the placental samples were fixed in $2.5 \%$ glutaraldehyde in $0.2 \mathrm{M}$ S-collidine $\mathrm{pH} 7.4$, post-fixed in $1 \%$ osmium tetroxide in $0.2 \mathrm{M} \mathrm{S}$-collidine $\mathrm{pH}$ 7.4 , dehydrated in increasing concentrations of acetone and embedded in EMbed 812 resin. This ultra-thin sections (60 $\mathrm{nm}$ ) were cut and placed on cupper grids, counterstained in uranyl acetate and lead citrate. The sections were examined in transmission electronic microscope Elmiskop 101 (Siemens, Germany).

\section{RESULTS}

At 30 days of pregnancy, no immunolabelling for FAS B-10 was seen in the villi, blood vessels and glands, whereas in placental connective tissue weak labelling was observed. Immunoreactivity of FAS C-20 was found moderate in the endometrial connective tissue and weak in the mesenchyme, while no labelling was seen in the villi, glands and blood vessels. Villi, blood vessels and glands were not reactive to 
membrane receptor DR4 but its expression was moderate in endometrial and mesenchymal connective tissues.

At 55 days of pregnancy moderate immunolabelling for FAS B-10 was seen in the villi and endometrial connective tissue, weak expression in blood vessels and moderate labelling in glands. Similary, FAS C-20 expression was moderate in the villi and in endometrial connective tissue. In this gestational period no expression of the DR4 was observed neither in the villi nor in maternal blood vessels, but weak and moderate staining was seen in mesenchyme and endometrial connective tissue, respectively.

At late pregnancy, immunoreaction detected weak labelling for FAS B-10 in mesenchymal tissue but no staining in villi and blood vessell. FAS C-20 expression was found negative in villi, moderate in mesenchymal connective tissue and weak in blood vessels. For DR4 receptors, the immunolabelling was negative in villi and blood vessels, and moderate in mesenchymal tissues.
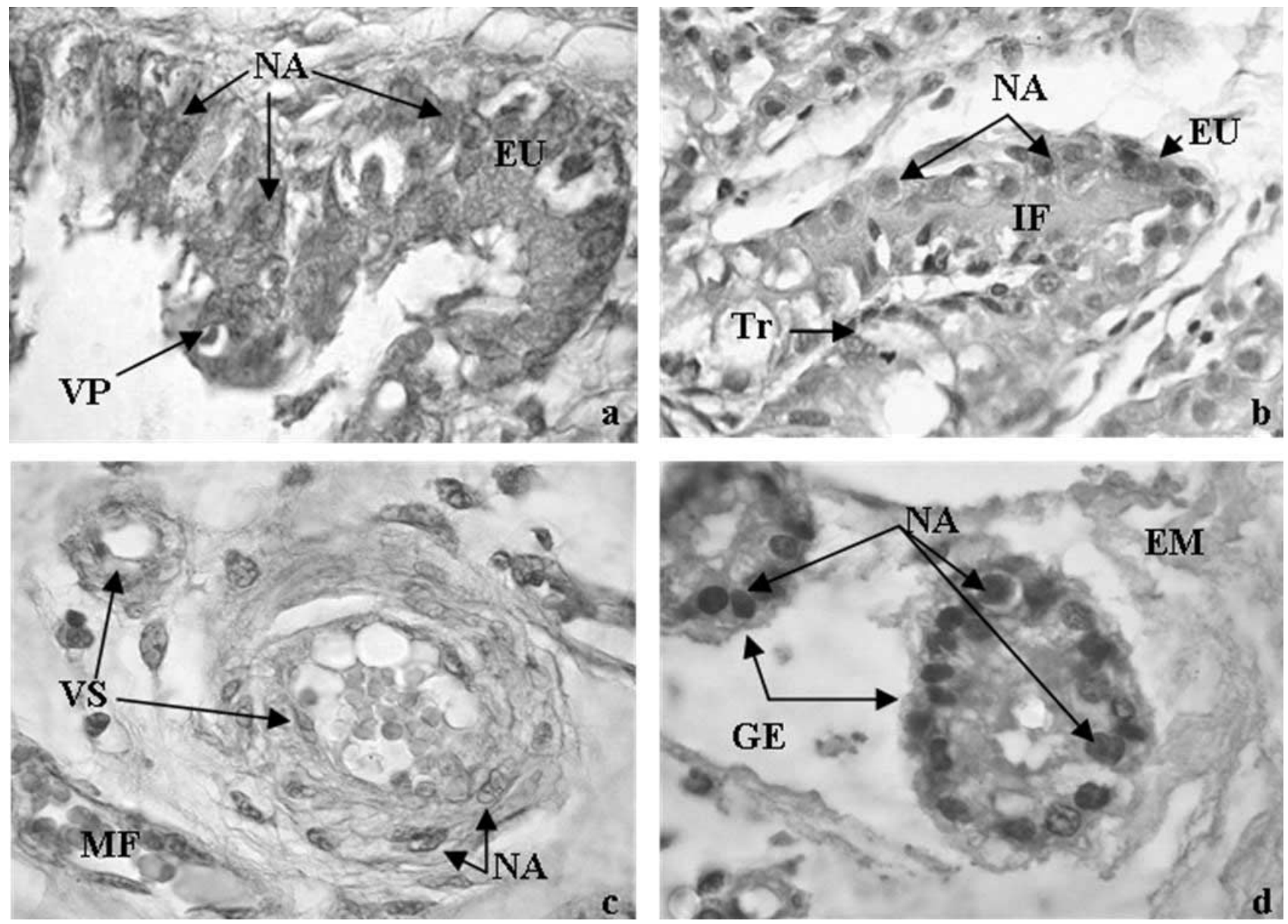

Fig. 2. Apoptotic nuclei labelled with TUNEL observed in porcine placenta of \pm 30 (a and c) and \pm 55 (b and d) days of gestation (1000x). EM: maternal endometrium, EU: uterine epithelium, GE: endometrial glandular epithelium, IF: maternal-fetal interface, MF: fetal mesenchyme, NA: apoptotic nuclei, Tr: trophoblastic epithelia, VP: placental villi, VS: blood vessel. 


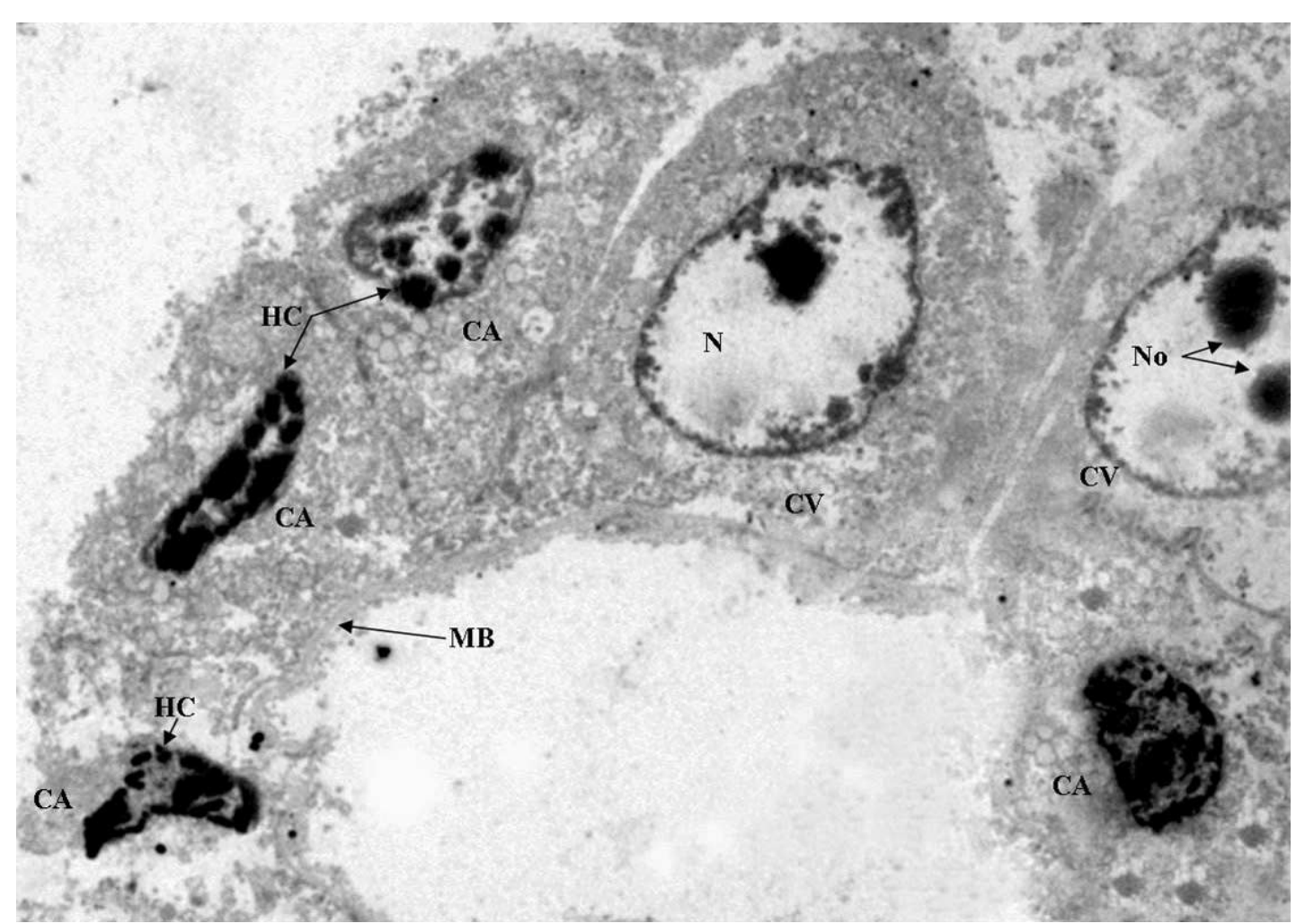

Fig. 3. Microphotography of placenta of day 55 of pregnancy, obtained by electronic microscopy of transmission. Viable and apoptotic cells are observed in placental villi (2750x). CA: apoptotic cell, CV: viable cell, HC: condensed heterochromatin, MB: basal membrane, N: nuclei, No: nucleoli.

and high expression of FAS membrane receptors and others belonging to the TNF R-1 superfamily (Fig. 1). At 55 days, the distribution of the immunolabelling intensity of the three apoptosis receptors diminished, predominating the expression of FAS receptors. At late pregnancy a remarkable increase in the expression of the apoptosis receptors was observed, especially for DR4 receptors.

Figure 2 shows apoptotic cells in uterine and trophoblastic epithelia of pig placentas of 30 and 114 days of pregnancy respectively, which marked positively with the TUNEL technique. Nuclei at very initial phases in chromatinic marginalization can be also identified. At day 30 immunoreactivity was in patches, whereas at mid and late pregnancy it was lineal.

Figure 3 shows an ultra-thin section of a placenta of \pm 55 days of pregnancy. In uterine epithelium viable cell are observed with great central nuclei visible euchromatin and nucleoli, some other cells are seen with apoptotic ultrastructural characteristic showing picnotic nuclei, condensation, presence of heterochromatin and increase of intracellular density. In cells in which apoptosis appears to be more advanced loss of intercellular contact was observed.

\section{DISCUSSION}

Our results indicate that at the beginning of the porcine gestation the cellular remodelling of the placenta may be occurring through FAS membrane receptor and other members of the TNF-R1 superfamily. The HScore percentages of this receptors in the first gestational period correlate to the apoptosis levels by way of FAS comparable with those observed in organs in situation of immunological privilege as it is the placenta.

During porcine gestation a correct metabolic exchange between maternal and fetal systems is critical to meeting the nutritional demands of the conceptus. The adequate remodelling of placental cell through apoptotic processes is essential for the maintenance of homeostasis of this transitional organ with advancing gestation (Dantzer \& Leiser; Finch et al., 2004). The post-implantational period is when an important angiogenesis takes place, which is necessary to obtain the suitable transport of nutrients to the embryo/fetus (Finch et al., 2004; Merkis et al., 2006). In humans and pigs, low weight at birth is the most important factor of neonatal morbidity and mortality; in pigs the faults that occur at 30 days of pregnancy would directly influence 
the size of the litter (Lawrence, 1993). The early embryonic losses without specific cause, such as faults in the fetal maternal recognition, in the embryonic morphogenesis, the transport of nutrients or the regulation of the apoptosis process, among others, fluctuate between 30 to $52 \%$ (Pope; Bosch et al.).

At 55 days of pregnancy the HScore levels for DR4 receptors were negative, suggesting that apoptosis observed is not mediated by the extrinsic route. Moreover, in this period low values for FAS were found, suggesting that apoptosis may be occurring through FAS route. At late pregnancy the apoptotic indices increase detecting the programmed cellular death by extrinsic route through FAS and DR4 receptors.

The increase of the expression of these receptors is directly related to the increase of blood vessels of medium caliber (Inoue et al.; Merkis et al., 2006). In the maintenance of the normal tissue homeostasis, the balance between the cell death and the cellular proliferation plays an essential role. This can be particularly important for the satisfactory development of the pig gestation. The alterations of the programmed cellular death during placentation due to fails in recruited molecules FAS system might have an influence in pregnancy success (Jersak \& Bischof).

At 30 days of pregnancy apoptosis to all receptors studied in villi was not detected, although apoptotic nucleus in patch forms in this tissue were observed with TUNEL. We found that the reduction of the placental apoptotic activity that was observed at mid gestation ( \pm 55 days) corresponds to the moment when the largest placental growth occurs. It is in this period that fetuses increase in size instead of the placental. At late pregnancy, due to the type of epitheliochorial and adecidua placenta, the apoptosis expression increases to necessary levels so that the farrowing can be induced.

Through TEM conventional technique it was possible to observe in placental villi at early, mid and late gestation, epithelial cells with tipical ultrastructural characteristics of an apoptotic process.

In conclusion, according to our results, throughout the pig gestation placental apoptosis would occur through FAS and TNF R-1 receptors. Moreover, the high levels of apoptosis through extrinsic route of signaling observed at early and late gestation, would coincide with the elevated cell remodelling characteristic of both gestational periods. Moreover, the apoptosis observed in porcine placentas at term would be a necessary phenomenon to favor the processes triggering the farrowing, as seen in other placentation classes.

The relevance of our results is based upon the missing information concerning with the relation between apoptosis and placental remodelling in species of high productive value, such as the pig, specially in crossbred animals, characteristic of our geographical area livestock activity. Therefore, given the type of placentation present in gilts, epitheliochorial and non invasive, the expression of apoptosis observed in maternal and fetal villi throughout gestation would enhance cell remodelling in the placentalendometrial interface and, in consequence, the placental efficiency. The knowledge of the mechanisms that influence the apoptotic routes during pig placentation may help to generate new strategies useful for increasing the embryo survival in pigs, a species of high productive value.

MERKIS, C.; CRISTOFOLINI, A.; SANCHIS, E. \& KONCURAT, M. Expresión de los receptores de muerte celular FAS/CD95 y DR4 durante la placentación porcina. Int. J. Morphol., 28(3):829-834, 2010.

RESUMEN: La apoptosis es un proceso fisiológico, dinámico y permanente a través del cual un organismo elimina células indeseables sin provocar una respuesta inflamatoria. El objetivo del presente trabajo fue estudiar la expresión de los receptores de la vía extrínseca de apoptosis, FAS, DR4 y otros miembros de la superfamilia TNF-R1, la fragmentación del ADN y la apoptosis celular a través de TEM, en muestras placentarias del inicio, la mitad y el final de la gestación, hacia el día \pm 30 , \pm 55 y \pm 114 de preñez, respectivamente. Se realizaron cortes histológicos de las muestras placentarias fijadas en formol tamponado. Para la detección de los receptores de apoptosis se realizaron técnicas inmunohistoquímicas, para el estudio de la fragmentación del ADN se utilizó el ensayo TUNEL y para el análisis de la ultraestructura celular apoptótica la técnica convencional de TEM. La inmunolocalización de los receptores de muerte celular al inicio de la preñez porcina sugiere el rol de la apoptosis en la remodelación celular placentaria. Hacia el día 55 de preñez, la apoptosis detectada ocurriría únicamente a través de la vía del receptor FAS, no del receptor DR4. Al final de la gestación, se detectó un incremento de la apoptosis y la expresión de ambos receptores, indicando que la muerte celular a través de la vía de señalización extrínseca estaría inducida por los receptores FAS y DR4. En conclusión, la inmunolocalización de los receptores FAS y otros miembros del TNF-R1, los resultados de TUNEL y la ultraestructura celular apoptótica observada en la placentación porcina, indican que la apoptosis detectada ocurre por diferentes vías de inducción a lo largo de la gestación.

PALABRAS CLAVE: FAS/CD95; DR4 y superfamilia TNF-R1; Receptors de apoptosis; Placenta porcina. 


\section{REFERENCES}

Adams, J. M. Ways of dying: multiple pathways to apoptosis. Genes Dev., 17:2481-95, 2003.

Ameisne, J. C. On the origin, evolution, and nature of programmed cell death: a timeline of four billion years. Cell Death Differ., 9:367-93, 2002.

Amoroso, E. Placentation. In: Marshall's Physiology of Reproduction. Parkes, A. S. (Ed). Vol 2. London, Longmans Green, 1952. pp.127-311.

Barnhart, B. C.; Alappat, E. C. \& Peter, M. E. The CD95 Type I/ Type II model. Semin. Immunol., 15:185-93, 2003.

Bosch, R.; Alanis, G.; Allende, R.; Blanch, M.; Bosch, P. \& Callejas, S. En: Actualización en temas de reproducción animal. Bosch, R. A. (Ed). Argentina, Ed. Universidad Nacional de Río Cuarto, 2001. pp.150-2.

Cristofolini, A.; Merkis, C.; Zubeldía, D.; Barroso, F.; Lloret, M.; Sanchis, G.; Vaquer, V. \& Koncurat, M. FAS B-10, FAS C20 and TRAIL expression during porcine placentation. Biocell, 31(1):187, 2007.

Dantzer, V. Electron microscopy of the initial stages of placentation in the pig. Anat. Embryol., 172:281-93, 1985.

Dantzer, V. \& Leiser, R. Initial vascularization in the pig placenta: I. Demostration of non-glandular areas by histology and corrosion casts. Anat. Rec., 238:177-90, 1993.

Finch, A.; Yang, L.; Nwagwu, M.; Page, K.; McArdle, H. \& Ashworth, Ch. Placental transport of leucine in a porcine model of low birth weight. Reproduction, 128:229-35, 2004.

Fink, S. L. \& Cookson, B. T. Apoptosis, pyroptosis, and necrosis: mechanistic description of dead and dying eukaryotic cells. Infect. Immun., 73(4):1907-16, 2005.

Hardy, K.; Spanos, S.; Becker, D.; Iannelli, P.; Winston, R. \& Stark, J. From cell death to embryo arrest: mathematical models of human preimplantation embryo development. Proc. Natl. Acad. Sci. USA, 98:1655-60, 2001.

Inoue, N.; Manabe, N.; Matsui, T.; Maeda, A.; Nakagawa, S.; Wada, S. \& Miyamoto, H. Roles of tumor necrosis factorrelated apoptosis-inducing ligand signaling pathway in granulosa cell apoptosis during atresia in pig ovaries. $J$. Reprod. Dev., 49(4):313-21, 2003.

Jerzak, M. \& Bischof, P. Apoptosis in the first trimester human placenta: the role in maintaining immune privilege at the maternal-foetal interface and in the trophoblast remodelling. Eur. J. Obstet. Gynecol. Reprod. Biol., 100(2):138-42, 2002.
King, K. \& Cidlowski, J. Cell cycle regulation and apoptosis. Annu. Rev. Physiol., 60:601-17, 1998.

Lavrik, I. N.; Golks, A. \& Krammer, P. H. Caspases: pharmacological manipulation of cell death. J. Clin. Invest., 115(10):2665-72, 2005.

Lawrence, J. By the year 2000: More pigs from fewer sows. Natl. Hog. Farmer, 12:22-4, 1993.

Leiser, R. \& Kaufmann, P. Placental structure: in a comparative aspect. Exp. Clin. Endocrinol., 102:122-34, 1994.

Marrable, A. The embryonic pig: A chronological account. London, Pitman Medical, 1971.

Merkis, C.; Cristofolini, A.; Franchino, M.; Sanchis, E.; Moschetti, E. \& Koncurat, M. Angiogénesis placentaria durante la gestación porcina. REDVET, 7 (4):1-4, 2006.

Merkis, C.; Cristofolini, A. \& Koncurat, M. Apoptotic phenomena during porcine placentation. REDVET, 2007. Disponible en: www.veterinaria.org/revistas/redvet/n010107.html.

Pope, W. Embryonic mortality in swine. In: Embryonic mortality in domestic species. Zavy, M. T. \& Geisert, R. D. (Eds.) Boca Raton, CRC Press Inc., 1994. pp.53-77.

Selam, B.; Kayisli, U. A.; Mulayim, N. \& Arici, A. Regulation of Fas ligand expression by estradiol and progesterone in human endometrium. Biol. Reprod., 65:979-85, 2001.

van der Lende, T. \& van Rens, B. T. Critical periods for foetal mortality in gilts identified by analysing the length distribution of mummified foetuses and frequency of non-fresh stillborn piglets. Anim. Reprod. Sci., 75:141-50, 2003.

van Gurp, M.; Festjens, N.; van Loo, G.; Saelens, X. \& Vandenabeele, P. Mitochondrial intermembrane proteins in cell death. Biochem. Biophys. Res. Commun., 304:487-97, 2003.

Yang, E. \& Korsmeyer, S. Molecular thanatopsis: a discourse on the bcl-2 family and cell death. Blood, 88:386-401, 1996.

Correspondence to:

Cecilia Inés Merkis

Electronic Microscopy Area

Faculty of Agronomy and Veterinary

National University of Río Cuarto

National Route $\mathrm{N}^{\circ} 36, \mathrm{Km} 601$

Río Cuarto. CP: 5800. Córdoba

ARGENTINA

Tel: 54-358-4676165

Email: cmerkis@ayv.unrc.edu.ar

Received: 25-06-2010

Accepted: $12-07-2010$ 